Article

\title{
Highly efficient and clean synthesis of 1-amino-2-acetylanthraquinone by copper-catalyzed reductive cleavage of isoxazole motif
}

\author{
Zhongkui Zhao*, Renzhi Li, Yu Li \\ State Key Laboratory of Fine Chemicals, Department of Catalysis Chemistry and Engineering, School of Chemical Engineering, Dalian University of \\ Technology, Dalian 116024, China
}

A R T I C L E I N F O

Article history:

Received 10 October 2013

Accepted 4 November 2013

Published 20 March 2014

Keywords:

Copper catalyst

Reductive ring-cleavage

1-Amino-2-acetyl anthraquinone

3-Methylanthra[1,2-c]isoxazol-6,11-dione

Clean synthesis

\begin{abstract}
A B S T R A C T
A clean and highly efficient synthesis of 1-amino-2-acetylanthraquinone via reductive isoxazole ring cleavage of 3-methylanthra[1,2-c]isoxazole-6,11-dione catalyzed by trace copper using hydrazine hydrate as a clean reducing agent and water as a green reaction medium under mild reaction conditions was investigated. Various transition-metal catalysts were screened for the reductive ring-opening reaction, and $\mathrm{Cu}\left(\mathrm{NO}_{3}\right)_{2}$ was shown to be an excellent catalyst. A conversion of $97.2 \%$ and 1-amino-2-acetylanthraquinone selectivity greater than $95 \%$ were obtained in the presence of $2.6 \mathrm{~mol} \% \mathrm{Cu}\left(\mathrm{NO}_{3}\right)_{2}$ (turnover number 38) with 1.3 equiv. of hydrazine hydrate for $2 \mathrm{~h}$ in water. The structure of the product was confirmed by ${ }^{1} \mathrm{H}$ nuclear magnetic resonance spectroscopy and mass spectrometry; the main byproduct was hydroxyl-substituted 1-amino-2-acetylanthraquinone. A possible reaction mechanism for the copper-catalyzed ring cleavage of 3-methylanthra[1,2-c]isoxazole-6,11-dione with hydrazine hydrate was proposed.
\end{abstract}

(C) 2014, Dalian Institute of Chemical Physics, Chinese Academy of Sciences. Published by Elsevier B.V. All rights reserved.

\section{Introduction}

Many natural or artificial dyes and fine chemicals contain the isoxazole motif [1-4] and its ring cleavage is an important reaction. It has gained much attention in the dye/pigment and other chemical industries because isoxazole cleavage can produce a series of useful ortho-amino ketones, which are important organic intermediates in the dye, pigment, medical, and petrochemical fields [5-7]. 1-Amino-2-acetylanthraquinone is an ortho-amino ketone, and it is a key intermediate in the production of dyes and pigments such as Vat blue 66 [8].

Significant efforts have been made to achieve reductive cleavage of isoxazoles for the efficient synthesis of ortho-amino ketones, and this is considered to be one of the "Holy Grails" of synthetic chemistry. However, the reported methods for the reductive cleavage of isoxazoles have limitations. The most useful method for the reductive cleavage of isoxazoles to ortho-amino ketone derivatives is hydrogenation by using precious metals such as Pd [9-13] or Pt [10,11] as catalysts, but substrate groups susceptible to reduction do not survive [12]. Non-precious Raney Ni [14] has also been used in isoxazole hydrogenation, but requires careful handling and fine control of the reaction conditions. Moreover, hydrogenation using $\mathrm{H}_{2}$ as the reducing agent generally requires harsh conditions such as high temperature and high pressure. In recent years, many researchers have proposed alternative strategies to hydro-

\footnotetext{
* Corresponding author. Tel/Fax: +86-411-84986354; E-mail: zkzhao@dlut.edu.cn This work was supported by the Chinese Ministry of Education via the Program for New Century Excellent Talents in University (NCET-12-0079) and the Fundamental Research Funds for the Central Universities (DUT12LK51).
} 
genation for the reductive cleavage of isoxazoles, via electron transfer by $\mathrm{AlI}_{3}$ [15], $\mathrm{FeCl}_{2}$ [16-18], $\mathrm{TiCl}_{3}$ [19], $\mathrm{SmI}_{2}$ [20,21], or $\mathrm{Me}_{3} \mathrm{Sil}[22,23]$, but these methods require extremely anhydrous conditions. In addition, non-catalytic stoichiometric reduction processes with $\mathrm{FeSO}_{4}$ [24], $\mathrm{Na}_{2} \mathrm{~S}_{2} \mathrm{O}_{4}$ [25,26], Mo(CO) 6 $[9,11]$, or $\mathrm{CuI}[27]$ as reducing agent have been used in the synthesis of ortho-amino ketones. Unfortunately, large amounts of chemical reagents are required and many waste products are formed. The development of clean and highly efficient methods for reductive cleavage reactions under mild reaction conditions is therefore important. This approach is pursuing to resolve the problems that are still encountered in the production of ortho-amino ketones via ring opening of isoxazole motifs.

Hydrazine hydrate is a highly active and relatively clean reducing agent with $\mathrm{N}_{2}$ as the sole byproduct, and it has been widely used under mild reaction conditions in the synthesis of dyes, medical products, and pesticides. Guanidine [28], reduced graphene oxide [29], precious metals [30], and non-precious metal oxides [31,32] have been widely used in catalytic reductions using hydrazine hydrate in organic and inorganic synthesis [33,34]. Hydrazine hydrate is a popular reducing agent in many synthetic fields, but a low-cost and highly efficient catalyst for this synthetic process still needs to be found.

In our previous research [35], hydrazine hydrate was established to be a relatively clean and efficient reducing agent in the ring-opening reaction of 3-methylanthra[1,2-c]isoxazole-6,11dione to 1-amino-2-acetylanthraquinone. The development of more-efficient catalysts is an increasingly important goal for both economic and environmental reasons. The aim of this work was to develop an efficient catalytic system for the reductive ring cleavage of 3-methylanthra[1,2-c] isoxazole-6,11-dione to yield 1-amino-2-acetylanthraquinone (Scheme 1). To the best of our knowledge, this work firstly represents a highly-efficient approach of $\mathrm{Cu}$ catalyzed ring opening of 3-methylanthra[1,2-c]isoxazole-6,11-dione for synthesizing 1-amino-2acetylanthraquinone using hydrazine hydrate as the reducing agent.

\section{Experimental}

\subsection{Materials and instruments}

All reagents were purchased from Aladdin and were used without further purification. ${ }^{1} \mathrm{H}$ nuclear magnetic resonance (NMR) spectra were obtained using a Bruker Avance II 400 $\mathrm{MHz}$ instrument at room temperature, with tetramethylsilane as the internal standard; coupling constants $(D)$ were measured in hertz. Mass spectra (MS) were recorded using an HP1100LC/ MSD spectrometer.

\subsection{Catalytic reaction}

In a typical experimental procedure, 3-methylanthra[1,2-c] isoxazole-6,11-dione (2.63 g, $100 \mathrm{mmol}$ ) was placed in a onenecked round-bottomed flask $(25 \mathrm{~mL})$, and then deionized water $(3.0 \mathrm{~mL})$ and $2.6-5 \mathrm{~mol} \%$ of catalyst were added. The reaction mixture was stirred at room temperature for $30 \mathrm{~min}$ to ensure good dispersion, and then the desired amount of hydrazine hydrate was added to the mixture with continuous stirring. The mixture was continuously stirred for the desired reaction time. After the reaction, the mixture was filtered, and the obtained solid product was washed with deionized water and dried at $105^{\circ} \mathrm{C}$ overnight. The obtained product was quantitatively analyzed using high-performance liquid chromatography (HPLC). The conversion was calculated as the percentage of 3-methylanthra[1,2-c]isoxazole-6,11-dione consumed based on the HPLC results. In all cases, more than 95\% selectivity for 1-amino-2-acetylanthraquinone (MS, M + $1=266$ ) was obtained, and the main byproduct was hydroxy-substituted 1amino-2-acetylanthraquinone (MS, $\mathrm{M}+1=283$ ). Red powder, m.p. $222-226^{\circ} \mathrm{C}$; ${ }^{1} \mathrm{H} \mathrm{NMR}\left(\mathrm{CDCl}_{3}\right): \delta 2.68\left(3 \mathrm{H}, \mathrm{s}, \mathrm{CH}_{3}\right), 7.55(1 \mathrm{H}$, d), 7.72-7.83 $(2 \mathrm{H}, \mathrm{t}), 8.16(1 \mathrm{H}, \mathrm{d}), 8.23-8.32(2 \mathrm{H}, \mathrm{d}), 9.51$, and $9.92\left(2 \mathrm{H}, \mathrm{s}, \mathrm{NH}_{2}\right)$; MS (APCI, $\left.m / z\right)$ for 1-amino-2-acetylanthraquinone $[\mathrm{M}+1]^{+} 266$.

\section{Results and discussion}

\subsection{Effect of transition metal type}

Various transition-metal nitrates were screened in the reductive cleavage of 3-methylanthra[1,2-c]isoxazole-6,11-dione for the synthesis of 1-amino-2-acetylanthraquinone. The results are summarized in Table 1 . As shown in Table 1 that the type of transition metal significantly influences the ring-opening reaction. The best catalytic performance was achieved us-

\section{Table 1}

Catalytic reduction of 3-methylanthra[1,2-c]isoxazole-6,11-dione.

\begin{tabular}{lcc}
\hline Entry & Catalyst & Conversion ${ }^{a}(\%)$ \\
\hline 1 & $\mathrm{Co}\left(\mathrm{NO}_{3}\right)_{2}$ & 11.6 \\
2 & $\mathrm{Ni}\left(\mathrm{NO}_{3}\right)_{2}$ & 10.8 \\
3 & $\mathrm{Fe}\left(\mathrm{NO}_{3}\right)_{3}$ & 9.0 \\
4 & $\mathrm{Cu}\left(\mathrm{NO}_{3}\right)_{2}$ & 96.8 \\
5 & blank & 6.5 \\
$6^{\text {b }}$ & blank & 6.6 \\
\hline
\end{tabular}

Reaction conditions: $5 \mathrm{~mol} \%$ of catalyst dosage (molar percentage of catalyst to 3-methyl-anthra-[1,2-c]-isoxazol-6,11-dione), 4 equiv. hydrazine hydrate, $3 \mathrm{~mL} \mathrm{H}_{2} \mathrm{O}$, room temperature, $1 \mathrm{~h}$.

a Determined by HPLC after the reaction (in all cases, the selectivity is above 95\%).

b Reaction time: $24 \mathrm{~h}$.

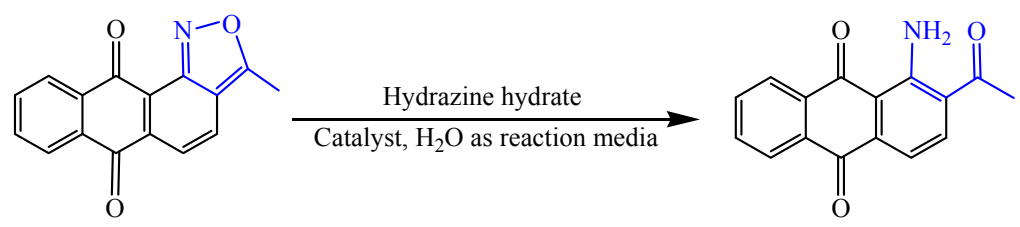

Scheme 1. Catalytic reductive ring cleavage of 3-methylanthra[1,2-c]isoxazole-6,11-dione for highly efficient synthesis of 1-amino-2-acetylanthraquinone using hydrazine hydrate as reducing agent. 
Table 2

Catalytic reaction results over different copper salts.

\begin{tabular}{lccc}
\hline Entry & Catalyst & Time (h) & Conversion ${ }^{\text {a }}(\%)$ \\
\hline 1 & $\mathrm{CuSO}_{4}$ & 1 & 85.3 \\
2 & $\mathrm{CuSO}_{4}$ & 2 & 98.3 \\
3 & $\mathrm{CuCl}_{2}$ & 1 & 78.4 \\
4 & $\mathrm{CuCl}_{2}$ & 2 & 98.1 \\
5 & $\mathrm{CuCl}$ & 1 & 96.0 \\
6 & $\mathrm{Cu}$ & 1 & 86.6 \\
7 & $\mathrm{Cu}$ & 2 & 94.2 \\
8 & $\mathrm{Cu}\left(\mathrm{NO}_{3}\right)_{2}$ & 1 & 96.8 \\
\hline
\end{tabular}

Reaction conditions: $5 \mathrm{~mol} \%$ of catalyst dosage, 4 equiv. hydrazine hydrate, $3 \mathrm{~mL} \mathrm{H}_{2} \mathrm{O}$, room temperature.

a Determined by HPLC after the reaction (in all cases, the selectivity is above $95 \%$ ).

ing $\mathrm{Cu}\left(\mathrm{NO}_{3}\right)_{2}$ as catalyst, giving $96.8 \%$ of 3-methylanthra[1,2-c]isoxazole-6,11-dione conversion. However, the conversions were only $11.6 \%, 10.8 \%$, and $9.0 \%$ over $\mathrm{Co}\left(\mathrm{NO}_{3}\right)_{2}$, $\mathrm{Ni}\left(\mathrm{NO}_{3}\right)_{2}$, and $\mathrm{Fe}\left(\mathrm{NO}_{3}\right)_{3}$, respectively. The blank experiment results showed that the conversion was only $6.5 \%$ when the same reaction conditions were used except for in the absence of $\mathrm{Cu}\left(\mathrm{NO}_{3}\right)_{2}$. Even when the reaction time was extended to $24 \mathrm{~h}$, there was still no noticeable increase in the conversion. We can therefore conclude that $\mathrm{Cu}\left(\mathrm{NO}_{3}\right)_{2}$ is a promising catalyst for the reductive cleavage of 3-methylanthra[1,2-c]isoxazole-6,11dione for the production of 1-amino-2-acetylanthraquinone. Moreover, no detectable reaction occurs in the absence of hydrazine, suggesting that the reaction takes place via a catalytic reduction route; this is different from the reported method [27].

\subsection{Effect of copper salt type}

We then investigated the catalytic performances of various copper salts (Table 2). Under the same reaction conditions, the catalytic activity order was $\mathrm{Cu}\left(\mathrm{NO}_{3}\right)_{2}>\mathrm{CuCl}>\mathrm{Cu}>\mathrm{CuSO}_{4}>$ $\mathrm{CuCl}_{2} . \mathrm{Cu}\left(\mathrm{NO}_{3}\right)_{2}$ is the best catalyst for this ring-cleavage reaction. In the cases of $\mathrm{Cu}, \mathrm{CuSO}_{4}$, and $\mathrm{CuCl}_{2}$, extending the reaction time up to $2 \mathrm{~h}$ significantly increased the conversion to $94.2 \%$, $98.3 \%$, and $98.1 \%$, respectively. These results suggest that various copper salts, especially $\mathrm{Cu}\left(\mathrm{NO}_{3}\right)_{2}$, are highly-efficient catalysts for the mild and efficient ring cleavage of 3-methylanthra[1,2-c] isoxazole-6,11-dione to 1-amino-2-acetylanthraquinone with hydrazine hydrate as a relatively clean and highly active reducing agent.

\subsection{Effect of reaction conditions}

The effects of catalyst dosage, reducing agent, and reaction time on the synthesis of 1-amino-2-acetylanthraquinone were further investigated using $\mathrm{Cu}\left(\mathrm{NO}_{3}\right)_{2}$ as the catalyst (Table 3). The results showed that $96.2 \%$ of conversion (116 g product $\mathrm{g}^{-1}$ copper $\mathrm{h}^{-1}$ ) can be obtained over $\mathrm{Cu}\left(\mathrm{NO}_{3}\right)_{2}$ in the presence of 4 equiv. of hydrazine hydrate for $1 \mathrm{~h}$. Even if the amount of hydrazine hydrate is decreased to 1.3 equiv., $97.2 \%$ conversion is still obtained in the presence of $2.6 \mathrm{~mol} \%$ of $\mathrm{Cu}\left(\mathrm{NO}_{3}\right)_{2}$ for $2 \mathrm{~h}$. These results indicate that this catalyst system containing
Table 3

Optimum conditions with $\mathrm{Cu}\left(\mathrm{NO}_{3}\right)_{2}$ as catalyst.

\begin{tabular}{lcccc}
\hline Entry & $\begin{array}{c}\text { Catalyst dosage } \\
\text { (mol\%) }\end{array}$ & $\begin{array}{c}\text { Hydrazine } \\
\text { (equiv.) }\end{array}$ & $\begin{array}{c}\text { Time } \\
(\mathrm{h})\end{array}$ & $\begin{array}{c}\text { Conversion }^{\text {a }} \\
(\%)\end{array}$ \\
\hline 1 & 5 & 4 & 1 & 96.8 \\
2 & 2.6 & 4 & 1 & 96.2 \\
3 & 2.6 & 2.6 & 1 & 85.6 \\
4 & 2.6 & 1.3 & 1 & 72.6 \\
5 & 2.6 & 1.3 & 2 & 97.2 \\
\hline
\end{tabular}

Reaction conditions: $3 \mathrm{~mL} \mathrm{H}_{2} \mathrm{O}$, room temperature.

a Determined by HPLC after the reaction (in all cases, the selectivity is above 95\%).

$\mathrm{Cu}\left(\mathrm{NO}_{3}\right)_{2}$ and hydrazine hydrate is facile and efficient for the cleavage of 3-methylanthra[1,2-c]isoxazole-6,11-dione to 1-amino-2-acetylanthraquinone.

\subsection{Plausible reaction mechanism}

Based on the results above, we explored the mechanism of $\mathrm{Cu}$ catalysis in the presence of hydrazine hydrate. Table 1 shows that $\mathrm{Cu}\left(\mathrm{NO}_{3}\right)_{2}$ is a highly efficient catalyst for the reductive cleavage of 3-methylanthra[1,2-c]isoxazole-6,11-dione. From Table 2, it can be seen that an in situ reduced low-valent $\mathrm{Cu}$ species might be the active species in the $\mathrm{Cu}\left(\mathrm{NO}_{3}\right)_{2}$-catalyzed reductive ring opening of the isoxazole motif. We also performed experiments by mixing hydrazine hydrate with diverse transition-metal ( $\mathrm{Fe}, \mathrm{Cu}, \mathrm{Co}$, and $\mathrm{Ni}$ ) nitrates. It was found that the mixtures became muddy and changed color, suggesting that the high-valent metal ions have been reduced to low-valent ones, and even zero-valent metals. A combination of these phenomena with the results in Tables 1 and 2 suggests that in situ reduced low-valent $\mathrm{Cu}$ species may be mainly responsible for the catalytic reduction. We also performed experiments using stoichiometric amounts of $\mathrm{Cu}$ metal or $\mathrm{CuCl}$, but without adding hydrazine hydrate; quite low conversions were ob-

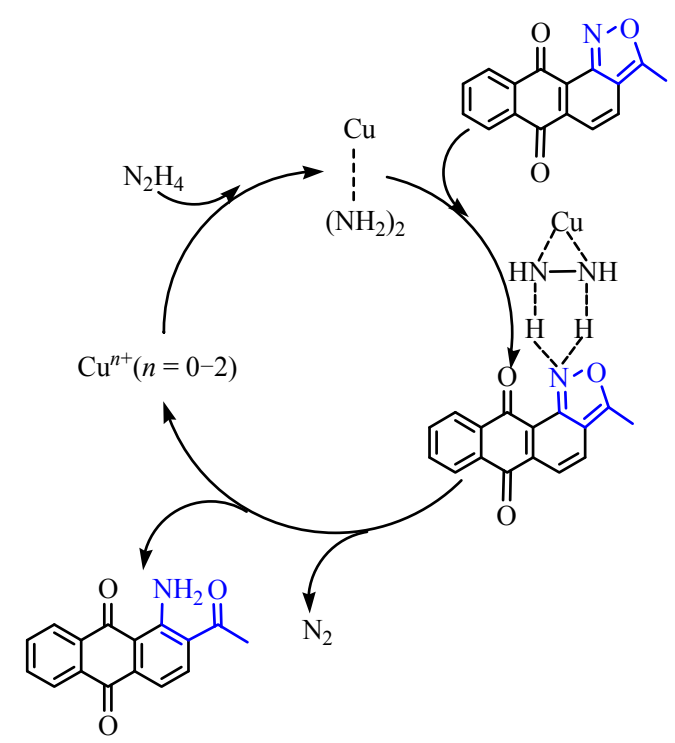

Scheme 2. Tentative mechanism for reductive cleavage of 3-methylanthra[1,2-c]isoxazole-6,11-dione in the presence of $\mathrm{Cu}$ catalyst to produce 1-amino-2-acetylanthraquinone. 
served. We therefore conjecture that the activation of hydrazine by the formation of a coordinate bond, or activation of the $\mathrm{N}-\mathrm{H}$ bond of hydrazine, not copper or low-valent copper ions themselves, enhances cleavage of the isoxazole ring [28,32,36]; a plausible reaction mechanism is shown in Scheme 2.

\section{Conclusions}

In summary, $\mathrm{Cu}\left(\mathrm{NO}_{3}\right)_{2}$ was found to be an excellent catalyst for the reductive ring cleavage of 3-methylanthra[1,2-c] isoxazole-6,11-dione to produce 1-amino-2-acetylanthraquinone using hydrazine hydrate as the reducing reagent in water. $97.2 \%$ of conversion and more than $95 \%$ of selectivity for 1-amino-2-acetylanthraquinone were obtained using $2.6 \%$ of $\mathrm{Cu}\left(\mathrm{NO}_{3}\right)_{2}$ to 3-methylanthra[1,2-c] isoxazole-6,11-dione and 1.3 equiv. of hydrazine hydrate for $2 \mathrm{~h}$ in water. A plausible reaction mechanism was proposed. It was clear that hydrazine hydrate was activated by interactions with $\mathrm{Cu}$ species, and this accelerated the ring-opening reaction of 3-methylanthra[1,2-c] isoxazole-6,11-dione. We believe that the copper-catalyzed ring cleavage of the isoxazole motif could be used to produce various ortho-amino ketones from different isoxazole-containing compounds, opening up a new avenue for mild and efficient reduction procedures in fine chemicals.

\section{References}

[1] Zhang X H, Wang L Y, Zhan Y H, Fu Y L, Zhai G H, Wen Z Y. J Mol Struct, 2011, 994: 371

[2] Li Y T, Chen C L, Hsu Y Y, Hsu H C, Chi Y, Chen B S, Liu W H, Lai C H, Lin T Y, Chou P T. Tetrahedron, 2010, 66: 4223

[3] Amino M S, Mahmoud A A, Badr S K, Gouda A S. J Surf Det, 2012, 15: 179

[4] Velcicky J, Soicke A, Steiner R, Schmalz H G. J Am Chem Soc, 2011, 133: 6948

[5] Zolfigol M A, Salehi P, Shiri M, Rastegar T F, Ghaderi A.J Iran Chem Soc, 2008, 5: 490

[6] Krasavin M, Busel A, Parchinsky V. Tetrahedron Lett, 2009, 50: 5945

[7] Zhang X S, Song X X, Li H, Zhang S L, Chen X B, Yu X H, Wang W. Angew Chem Int Ed, 2012, 51: 7282

[8] Zhao Z K, Li R Z, Li Y, Chen G T. CN Patent 102603547A. 2012
[9] Vergelli C, Giovannoni M P, Pieretti S, Di Giannuario A, Dal Piaz V, Biagini P, Biancalani C, Graziano A, Cesari N. Bioorg Med Chem, 2007, 15: 5563

[10] Walker G N.J Org Chem, 1962, 27: 1929

[11] Oster T A, Harris T M. J Org Chem, 1983, 48: 4307

[12] Caplan J F, Zheng R J, Blanchard J S, Vederas J C. Org Lett, 2000, 2: 3857

[13] Charest M G, Siegel D R, Myers A G. J Am Chem Soc, 2005, 127: 8292

[14] Akiba K, Kashiwagi K, Ohyama Y, Yamamoto Y, Ohkata K. J Am Chem Soc, 1985, 107: 2721

[15] Konwar D, Boruah R C, Sandhu J S. Chem Ind, 1989, 6: 191

[16] Auricchio S, Bini A, Pastomerlo E, Truscello A M. Tetrahedron, 1997, 53: 10911

[17] Kijima M, Nambu Y, Endo T. J Org Chem, 1985, 50: 1140

[18] Mohatt J L, Hu L H, Finneran K T, Strathmann T J. Environ Sci Technol, 2011, 45: 4793

[19] Angibaud P R, Venet M G, Filliers W, Broeckx R, Ligny Y A, Muller P, Poncelet V S, End D W. Eur J Org Chem, 2004: 479

[20] Fan X S, Zhang Y M. Tetrahedron Lett, 2002, 43: 7001

[21] Natale N R. Tetrahedron Lett, 1982, 23: 5009

[22] Konwar D, Boruah R C, Sandhu J S, Baruah J N. Synth Commun, 1984, 14: 1053

[23] Olah G A, Narang S C, Tetrahedron, 1982, 38: 2225

[24] Epple G, Flohr H. DE Patent 2912570A1. 1980

[25] Wilke K. US Patent 1830152. 1931

[26] Wilke K. US Patent 1830153. 1931

[27] Vasilevsky S F, Gornostaev L M, Stepanov A A, Arnold E V, Alabugin I V. Tetrahedron Lett, 2007, 48: 1867

[28] Lamani M, Guralamata R S, Prabhu K R. Chem Commun, 2012, 48: 6583

[29] Gao Y J, Ma D, Wang C L, Guan J, Bao X H. Chem Commun, 2011, 47: 2432

[30] Shil A K, Sharma D, Guha N R, Das P. Tetrahedron Lett, 2012, 53: 4858

[31] Sharma U, Verma P K, Kumar N, Kumar V, Bala M, Singh B. Chem Eur J, 2011, 17: 5903

[32] Marsh B J, Heath E L, Carbery D R. Chem Commun, 2011, 47: 280

[33] Kinjo R, Donnadieu B, Bertrand G. Angew Chem Int Ed, 2011, 50: 5560

[34] Britvin S N, Lotnyk A, Kienle L, Krivovihev S V, Depmeier W. J Am Chem Soc, 2011, 133: 9516

[35] Zhao Z K, Li R Z, Li Y. ScienceJet, 2013, 2: 41

[36] Daff T D, de Leeuw N H. Chem Mater, 2011, 23: 2718

\section{Graphical Abstract}

Chin. J. Catal., 2014, 35: 319-323 doi: 10.1016/S1872-2067(12)60743-8

Highly efficient and clean synthesis of 1-amino-2-acetylanthraquinone by copper-catalyzed reductive cleavage of isoxazole motif

Zhongkui Zhao*, Renzhi Li, Yu Li

Dalian University of Technology

A trace-copper-catalyzed reductive isoxazole-ring-cleavage strategy for clean and highly efficient production of 1-amino-2-acetylanthraquinone under mild reaction conditions was presented.

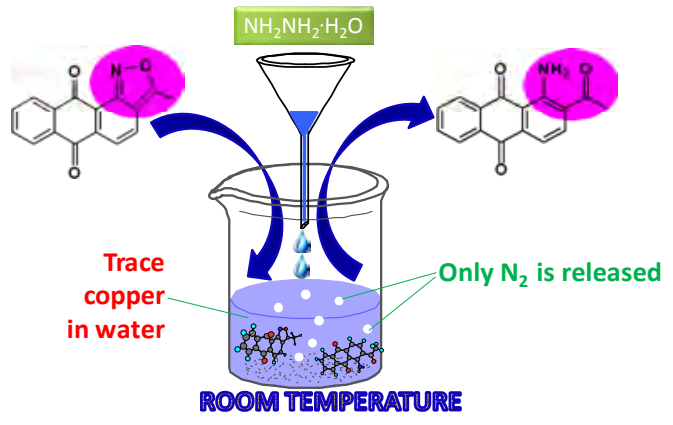




\title{
铜催化异噁唑还原开环清洁高效合成1-氨基-2-乙酰基葸醌
}

\author{
赵忠奎 ${ }^{*}$, 李仁志, 李 宇
}

大连理工大学精细化工国家重点实验室, 化工学院催化化学与工程系, 辽宁大连116024

摘要: 以水为反应介质, 水合肼为还原剂, 研究了痕量铜催化3-甲基葱醌-[1,2-c]-异噁唑还原开环反应以清洁高效合成1-氨基-2-乙 酰基葱醌, 考察了不同种类过渡金属硝酸盐的催化性能, 发现 $\mathrm{Cu}\left(\mathrm{NO}_{3}\right)_{2}$ 性能最好. 加入 $2.6 \%$ 的催化剂和 1.3 倍的水合肼, 在室温反 应 $2 \mathrm{~h}$, 底物转化率和目标产物选择性分别可达到 97.2\%和 95\%, TON达到 38 . 产品结构经氢核磁谱和质谱得以确证, 主要副产为 羟基取代的1-氨基-2-乙酰基葱醌. 此外, 提出了铜催化 3-甲基葱醌-[1,2-c]-异噁唑还原开环反应合成 1-氨基-2-乙酰基葋醌的可能 反应机理.

关键词: 铜催化剂; 还原开环; 1-氨基-2-乙酰基萝醌; 3-甲基葱醌-[1,2-c]-异噁唑; 清洁合成

收稿日期: 2013-10-10. 接受日期: 2013-11-04. 出版日期: 2014-03-20.

*通讯联系人. 电话/传真: (0411)84986354; 电子信箱: zkzhao@dlut.edu.cn

基金来源：教育部新世纪优秀人才支持计划(NCET-12-0079); 中央高校基本科研业务费专项资金(DUT12LK51).

本文的英文电子版由Elsevier出版社在ScienceDirect上出版(http://www.sciencedirect.com/science/journal/18722067). 